Robert BOŃKOWSKI* Uniwersytet Śląski w Katowicach
Оригинални научни рад

Примљен: 18.11.2019.

Прихваћен: 12.02.2020.

\title{
ФОНЕТСКЕ СКРАЋЕНИЦЕ У СРПСКОМ И ПОљСКОМ ФАМИЛИЈАРНОМ ЈЕЗИКУ - СЛИЧНОСТИ И РАЗЛИКЕ
}

\begin{abstract}
У раду је реч о лексици у фамилијарном/разговорном/жаргонском језику у смислу редукције појединих гласова и/или целих група гласова код Срба и код Пољака. За анализу су изабране апокопе, синкопе и аферезе у једном од јужнословенских и једном од западнословенских фамилијарних језика - то јест у српском и пољском језику. У раду је примењена поредбена метода анализе појаве елизије у два језика. Анализа језичке грађе довела је до закључка да српски и пољски фамилијарни језик често користе елизију и сва три типа фонетских скраћеница су присутна и у једном, и у другом језику (уз мало одступање од правила - једино је афереза чешћа појава код Срба, него код Пољака).
\end{abstract}

Кључне речи: српски језик, пољски језик, фамилијарни језик (говор), фонетика, елизија.

\section{1. Увод}

Анализирајући богату српску литературу, а пре свега различите речнике, може да се констатује да се фамилијарни језик мање више поистовећује са разговорним језиком. И још даље - са жаргоном. Битно је овде нагласити да је такав приступ проблему видљив у јужнословенској лингвистици. Добро образложење овог проблема, чини се, дао је Никола Кошћак у књизи Šrajbenzi spiku? Stilovi hrvatske žargonske i žargonizirane proze 1990-ih i 2000$i h^{1}$ (Кошћак 2018). Како пише аутор:

Odnos kolokvijalnog spram standardnog jezika u hrvatskom je kontekstu prilično kompleksan, i to ne samo zato što se kao varijante kolokvijalnog jezika mogu smatrati razni žargoni $i$ dijalekti ili zato što je status jednog vrlo važnog dijela (opće) kolokvijalnog leksika - vulgarizama

*robert.bonkowski@us.edu.pl

${ }^{1}$ Приступ свим цитираним веб-страницама у раду је од 10.09.2017. до 31.10.2019. 
i raznih pejorativnih izraza - spram norme često neodređen. Naime sudeći prema nekim funkcionalnostilističkim opisima, i tzv. razgovorni stil standardnoga jezika mogao bi se smatrati jednom - društveno osobitom - varijantom kolokvijalnog jezika. Tako o tom stilu na nekim mjestima piše Josip Silić, smatrajući ga ,potkodom standardnog jezika” (iako istovremeno ,, bez stroge ,kontrole' kodifikacijskih normi”), koji se kao „,neusiljen, prirodan, familijaran [подвукао - Р.Б.], , srednji'stil (...) rabi u običnome govoru (dakako: u govoru obrazovanih ljudi) ” (...). Izričito ga razlikujući od , supstandarda”, za Silića razgovorni stil ipak može sadržavati „, $i$ vulgarizama, $i$ dijalektizama, i regionalizama (provincijalizama), i barbarizama”. Silićev koncept razgovornoga stila pripušta dakle i ponešto dijalekatskih obilježja u sebe, i to - sudeći prema opisu-isključivo na leksičkoj razini, no žargonskih nimalo. (Točnije, prema njemu pojedine žargonske riječi - a žargone Silić određuje kao ,, specijalne jezike pojedinih socijalnih skupina ljudi” - u razgovorni stil ulaze tek kada postanu dijelom općega govora zajednice i prestanu biti žargonizmima, rekli bismo dakle: kad takve riječi postanu općekolokvijalizmima.) (Кошћак 2018).

Пошто је проблем комплексан, Кошћак пише даље:

Uobičajenije je međutim da se kao socijalno osobite varijante kolokvijalnoga jezika shvaćaju razni žargoni. Na tom je tragu određenje žargona Ranka Bugarskoga, prema kojemu se on može definirati kao „,neformalni i pretežno govorni varijetet nekog jezika koji služi za identifikaciju i komunikaciju unutar neke društveno određene grupe - po profesiji, socijalnom statusu, uzrastu i slično - čije članove povezuje zajednički interes ili način života, a koja uz to može biti i teritorijalno omeđena” (...). Bugarski razlikuje profesionalne, supkulturne i omladinske žargone, napominjući da su neki supkulturni žargoni istovremeno i karakteristično omladinski (Кошћак 2018).

Имајући у виду посебности између појединих стилова, тако схваћен појам фамилијарног/колоквијалног језика ипак, чини се, поједностављено оправдано омогућава ставити знак једнакости између фамилијарног језика и жаргона посебно, ако се узме у обзир компаративна анализа грађе двају језика и различити погледи на фамилијарни језик (то јест схватање и дефинисање) у српској и пољској литератури. На такав став утичу такође обимна српска литература и речници ${ }^{2}$.

\section{2. Општа лингвистичка дефиниција жаргона}

По мишљењу пољског лингвисте Кажимјежа Полањског (Kazimierz Polański), жаргон (али и арго, сленг, а у српској терминологији понекад и шатровачки говор -као нпр. језик криминалаца) јесте језик одређене друштвене групе, као што су ђаци, студенти, спортисти, војници, лекари и сл., који се рачуна као нижи по рангу у културном смислу. Разликује се од општег језика пре свега на лексичком, а не граматичком нивоу, као што је видљиво у односу на дијалекте. Лексичка одвојеност жаргона може бити мала, али и значајна - у овом другом случају жаргон престаје бити разумљив онима које га не користе и по својој природи такав жаргон се приближава тајном, шифрованом језику (Полањски 2003: 708). Жаргон карактеришу: посебан избор речи, честе посуђенице из страних језика и то, што се тиче овог текста, деформација облика речи. Сам термин 'жаргон' обухвата две следеће појаве:

\footnotetext{
${ }^{2}$ УП. наведену литературу.
} 
1) стручни, професионални жаргон (нпр. докторски жаргон, спортски жаргон и сл.);

2) супкултурни жаргон (везан за неку супкултуру, нараштај - на пример ђачки жаргон, студентски жаргон, жаргон наркомана и сл.).

\section{3. Начини творбе жаргона у српском и пољском језику}

Велика већина жаргонских лексичких особености како у српском, тако и у пољском језику (Самарџија/Селак 2001: 766-767) односи се на:

a) семантичко проширење општестандардних лексема, нпр.:

срп. мачка 1. 'девојка'; 2. 'згодна девојка'; пољ. kicia 'исто';

срп. иљьива '1. женски полни орган'; срб. и пољ. (śliwa) 2. 'модрица на оку/очима' и сл.

б) деривацију уз помоћ непродуктивних суфикса у српском стандардном језику, али веома продуктивних у жаргону, који су баш карактеристични за ту врсту језика, као што су суфикси -(ap)ош, - (j)aк, а у пољском језику уз помоћ продуктивних суфикса - $e k$ или - $k a$ нпр.:

срп. циинкарош 'информатор' < ичинкарити vi (< нем. zinken 'информисати, дати на знање'); двособюак 'двособни стан' < две собе и сл. исправа';

пољ. uniwerek $\mathrm{m}<$ uniwersytet 'универзитет'; legitka $\mathrm{f}<$ legitymacja 'карта, лична

в) $\quad$ метатезу - поремећај гласова или слогова у речи, нпр.: срп. бродо < добро; чкоде < дечко и сл. ${ }^{3}$

Ова је појава позната и у пољском жаргону, но знатно је ређа него у српском - нпр. пољ. јисhu < chuju! 'вокатив за вулг. мушки полни орган или wiśnia обично значење 'вишња' < świnia 'свиња' и сл.

г) губљење гласова у речима, скраћење речи које припадају стандардном језику, нпр.: срп. бус < аутобус (пољ. bus у значењу комби); срп. факс < факултет; срп. и пољ. профа < професор(ка) / profa $<$ $\operatorname{profesor}(\mathrm{ka})$ и сл.

д) посуђенице из страних језика, поготово (али не само) из енглеског, нпр.:

срп. фай 1. 'битно лице'; 2. 'позната особа'; 3. 'згодан мушкарац'> итал. faccia 'лице'; срп. фајтер 1. 'насилна особа'; 2. 'борац (нарочито у спорту)'< енгл. fighter 'борац';

срп. и пољ. флеш / fleš 1. 'нагла еуфорија под дејством дроге'; 2. 'стање по престанку дејства дроге' < амер. сленг. Flash;

ppajep у српском језику има више значења, најчешће: 1. 'згодан, млад, леп мушкарац'; 2. 'помодни младић'; 3. 'обестан младић', али исто и 'наиван мушкарац, незналица, почетник и слично' (пољ. frajer је познато само у овом последњем трећем значењу.) < нем. der Freier 'фрајер, конкурент' и сл..

\footnotetext{
${ }^{3}$ Потпуну анализу овог типа у савременој жаргонизацији у српском језику (у поређењу са другим јужнословенским језицима) представила је пољском читаоцу Ана Скиба (2011: 405412).
} 
ђ) сложенице и полусложенице, нпр:

срп. говнојед m 'аморална особа' < говно н + јести (* стсл. једти) $\mathrm{vi}+\varnothing$; мамојеб $\mathrm{m}$ 'кретен' $<$ мама $\mathrm{f}+$ вулг. јебати vі и тако даље.

пољ. mózgojeb m 'јефтино, хемијско вино (након његове употребе обично боли глава, а сам човек може да се понаша чудно' < mózg m 'мозак'+ вулг. jebać vi +

oczojebka $\mathrm{f}<o c z y \mathrm{f}$ pl. 'оči' + вулг. jebać vi + -ka 'батеријска лампа, светиљка'.

е) врло честу творбу вулгаризама.

Поред својствених лексичких и лексичко-семантичких конструкција жаргон карактерише такође врло богата, карактеристична фразеологија, нпр. срп. појавити се у новом издању 1. 'постати бољи'; 2. 'постати млађи' или бити у другом стағу срп. 'бити врло пијан' и 'бити трудна', пољ. być w innym stanie 'бити трудна'.

Грађа за анализу је преузета из српских речника жаргона, пре свега из Београдског фрајерског речника П. Имамија (Имами 2007), и пољских интернетских речника: Wasistdas.pl. Slang. Neologizmy. Mowa potoczna ${ }^{4}$ и Miejski słownik slangu i mowy potocznej ${ }^{5}$.

\section{4. Типови фонетских скраћеница у српском и пољском фамилијарном језику}

\section{0. Уводне напомене}

Фонетске скраћенице, иначе гласовне редукције (у лингвистичкој литератури познате такође под називом елизија) један су од типова жаргонизације. Ова појава, с једне стране, јесте лингвистичке, фонетске природе, а с друге је повезана с културом језика.

Предмет такве анализе нису акроними, речи које се користе да се означи да су нека слова, која се пишу заједно, само почетна, прва слова неких других речи која, иако сама за себе не значе ништа, заједно написана означавају неки појам. „Скраћеницу” разумемо у том случају као скраћени запис речи, која је саграђена од једног или неколико гласова (фона) и написана словима. Скраћенице могу да се односе на изостављање (прескакање) задњег, средишњег или почетног дела речи. Схваћен на овај начин термин у односу на српски (и пољски) омладински жаргон (као и колоквијални језик уопште) дозвољава да се нагласе три његова типа, то јест: 1) иницијалне скраћенице - апокопе, 2) медијалне скраћенице - синкопе и 3) финалне скраћенице - аферезе. Језичка економија јесте један од разлога за појаву скраћених речи. Према Весни Мухвић Димановски:

\footnotetext{
${ }^{4}$ http://www.vasisdas.pl/.

${ }^{5}$ https://www.miejski.pl/.
} 
Jezična se ekonomija često dovodi u vezu i s jezičnim posuđivanjem (...), tj. upravo se razlogom za uporabu tuđica (u kasnijoj fazi posuđenica) navodi želja za što kraćim načinom izražavanja. To zaista u mnogo slučajeva i jest tako, jer su se mnogobrojne posuđenice zadržale u nekome jeziku baš zahvaljujući tome što su kraće pa stoga i pogodnije od domaćih ekvivalenata koji se nude kao zamjena ili čak od već postojećih domaćih istoznačnica ili bliskoznačnica. U današnje se vrijeme zbog sve užurbanijega tempa života jezični izraz, posebice u svakodnevnoj uporabi, nastoji svesti na što je moguće manju mjeru; čini se da čovjek više nema vremena za opširnost, nego svoju komunikaciju obavlja brzo, kratko i sažeto. U tom smislu ne samo da se javlja česta uporaba kratkih, sadržajno obično vrlo preciznih, posuđenica, nego se i mnoge riječi iz domaćega vokabulara skraćuju i rabe u takvome skraćenom obliku u mnogim situacijama. Kada govorimo o domaćem vokabularu, mislimo na izvorne, autohtone rijeći nekoga jezika, ali i na stare, davno udomaćene posuđenice (Мухвић Димановски 2001: 193).

Анализирајући језичку грађу може се приметити да највећи део скраћеница, како у српском, тако и у пољском језику чине апокопе. Ситуација је нешто другачија у нашим језицима кад је реч о синкопи и аферези.

\section{1. Апокопа}

Апокопа се етимолошки изводи из грч. apokopç досл. 'одбијање, одсецање, одрезивање; apokopto: одбијем, одсечем), то јест од apokóptein 'одсећи'. Претпоставља се фонетска трансформација, која се базира на изостављању гласова на крају речи, на испадању једног или више гласова или слогова на крају речи. Ово је стилска фигура која настаје отпадањем гласова, а каткад и целог слога. Ова појава посебно се тиче самогласника без нагласка ${ }^{6}$ и слична je (или иста) у другим језицима (уп. нпр. пољ. tak из старопољског tako, или $i \dot{z}$ 'да' < из старопољског $i \dot{z} e$. У наше време апокопа се потврђује и у чешком [нпр. фамилијарно lip < lipe (из lépe) 'боље'] или у немачком језику (in Schlaff $<$ in Schlaffe 'у сну') (Полањски 2003: 50). Може се такође често срести у фамилијарном / жаргонском језику Срба и Пољака. Апокопе се могу поделити на неколико подгрупа. Прву од њих чине, могло би се рећи, „чисте” апокопе, то јест оне које не мењају или мењају граматички род у односу на изворни облик. У стварности, у току овакве промене долази само до изостављања гласа или гласова. Овај тип скраћеница у српском и пољском фамилијарном/жаргонском језику веома је продуктиван, уп.:

\subsection{1. Апокопа без промене рода са мушким граматичким родом}

Ово је врло популаран тип творбе у српском и пољском фамилијарном језику. Могућности и учесталост њихове творбе су (могло би се рећи) без ограничења. Ево неколико српских и пољских примера:

срп. Амер $\mathrm{m}<$ Американаи $\mathrm{m}$ (Ameri su 1945. trebali da odluče: baciti atomske bombe ili poslati Čak Norisa. Odlučili su se za humaniju varijantu'); бураз m hip. < буразери m 1. 'брат';

2. 'пријатељ' (Халиловић и др. 2002: 101) [< тур.-перс. birader (Имами 2007: 66) (baradar)

\footnotetext{
${ }^{6}$ У српском фамилијарном језику сугласници такође могу да буду предмет апокопе.

${ }^{7}$ http://www.ludomanija.net/vicevi/Chuck_Norris.htm (цитирани примери употребе са вебстраница у оригиналном запису).
} 
'брат' (Акопџањан 2010: 79)] (... bas sam to komentarisao sa burazom neki dan dok sam gledao ovaj film ... $\left.{ }^{8}\right)$; деген $\mathrm{m}<$ дегенерик m 'будала' (Maja bolesnu djecu naziva DEGENIMA?!...9); фуш m 'лоше обављен посао' < фушер m 1. 'забушант'; 2. 'надримајстор' < нем. Pfuscher m 'надримајстор'; гут m < гутьљај m; хаш $\mathrm{m}<$ хашии $\mathrm{m}$ (Nestalo je sarme, hasam paprikaš, nestalo je hedova zato pušim hašs ${ }^{10} ;$ кас $\mathrm{m}<$ касетофон $\mathrm{m} ;$ моб $\mathrm{m}<$ мобител $\mathrm{m} ;$ пајт $\mathrm{m}<$ nајташ 1. 'друг, пријатељ'; 2. 'цимер'; 3. 'ортак (у сумњивом послу)'; 4. 'истомишљеник' < mađ. pajtás 'друг, пријатељ'; шиз m < иизофреничар 1. 'психопата'; 2. 'ексцентрик'; 3. 'луда забава' [постати шиз 'постати ексцентричан', jesi li za neki šiz? 'јеси ли за неку луду забаву?' (Имами 2007: 470)]; Таш m < Ташмајдан 'парк и спортски центар у Београду’ и сл.

У пољском језику су скраћенице овог типа такође бројне. Начин творбе је исти као и у српском фамилијарном језику, уп.: alko $\mathrm{m}<$ alkohol $\mathrm{m}$; bro $\mathrm{m}$ < browar m 'место, где се производи пиво, само пиво' buk $\mathrm{m}<$ bukmacher $\mathrm{m}$ 'кладионичар, кладионица'; dezo $m$ < dezodorant m 'дезодоранс'; w porzo пропозициона фраза < w porzqdku пропозициона фраза 'у реду' и сл.

\subsection{2. Апокопа с променом рода}

\subsubsection{1. Апокопа с додатним суфиксом}

Овај тип апокопе карактеристичан је за знатан број жаргонизама. Овде можемо наћи такве српске примере као што су нпр: брис m 'бежање' < брисање n (од брисати) [bris! - gubi se!, uvatiti bris 'побећи' (Imami 2007: 62)]; цим m < цимағе $\mathrm{n} \mathrm{1.} \mathrm{'убеђивање,} \mathrm{наговарање';} \mathrm{2.} \mathrm{'досађивање,} \mathrm{гња-}$ важа'; 3. 'исцрпљивање'; 4. 'позивање телефоном' < ичимати vi (Inače, sve vreme razgovori preko mobilnog idu na naš račun, on samo pusti cim, a mi ga zovemo $^{11}$ ); дpn $\mathrm{m}<$ дрпање, дрписање $\mathrm{n} 1$. 'еротско пипање, грљење и миловање'; 2. 'крађа' < дpnamu, дрписати [Radi se o velikoj pljački po srbijanskom „,drp” sistemu - od svakog po malo, da se kao ne primeti (Герзић Б./Герзић Н. 2002: 66)]; фриз m < фризура f [što Ti je friz! - što imaš lepu frizuru! (Имами 2007: 148); Vrše se poslednje popravke friza, zateže se garderoba) (Герзић Б./ Герзић Н. 2002: 85) или фур $\mathrm{m}$ < фурање n 'бежање' и сл.

Пољски језик, чини се, није баш толико креативан у творби апокопе с променом граматичког рода у односу на изворну реч. У пољским интернетским речницима наведеним на почетку рада пронађен је само један пример апокопе овог типа, уп. : insta $\mathrm{f}<$ Instagram m.

\subsubsection{2. Апокопа с додатним суфиксом}

У оквиру ове групе налазе се апокопе, које у односу на основни облик не мењају врсту речи, као и оне које мењају врсту.

\subsubsection{1. Апокопа с додатним суфиксом без промене врсте речи}

Апокопе с додатним суфиксом без промене врсте речи у односу на изворну лексему чине доста бројну групу, како у српском, тако и у пољском језику, уп. нпр. српске примере: амфи $\mathrm{m}<$ амфетамин $\mathrm{m} ;$ факс $\mathrm{m}<$ факул-

\footnotetext{
${ }^{8} \mathrm{http}: / /$ vukajlija.com/zabava/posteri/245270.

${ }^{9} \mathrm{http}: / /$ www.forum-srbija.com/viewtopic.php?f=1\&t=2\&start=8980.

${ }^{10}$ www.inkarp.com/Youtube/profile/TheGenocyd96/.

${ }^{11} \mathrm{http}: / /$ www.putovanja.info/forum/topic/5362-jahorina/page_st_30.
} 
mem m (promašiti faks 'umesto na fakultet otići na neko drugo mesto' (Имами 2007: 125); Otišao sam do faksa i normalno pao ispit jer nikako nisam mogao da verujem и опо što mi se dogodilo ${ }^{12}$ ); физа $\mathrm{f}<$ физика $\mathrm{f}$ (Da stvar bude josh bolja svi iz fize imaju reshenja ${ }^{13}$ ) и сл.

Додатни суфикс често је деминутивне природе, што само потврђује да многе скраћене речи добијају наставке за деминутив и, премда немају изразито хипокористичко значење, ипак су афективно обојене и одражавају одређени ступањ присности с објектом који означавају (Мухвић Димановски 2001: 201). Ево неколико примера: компић $\mathrm{m}<$ компјутер $\mathrm{m} ;$ хомић $\mathrm{m}<$ хомосексуалаи $\mathrm{m}$ или цртаћ $\mathrm{m}<$ иртани филм $\mathrm{m}$.

У пољском језику овај тип творбе је такође врло популаран, уп. нпр.: fotka $\mathrm{f}<$ fotografia f 'фотографија'; uniwerek m < uniwersytet m 'универзитет'; legitka $\mathrm{f}<$ legitymacja f 'карта, лична исправа' и сл.

\subsubsection{2. Апокопа с додатним суфиксом и с променом врсте речи}

У већини случајева проблем појављивања ових скраћеница тиче се конверзије. Ова појава припада једној врсти деривације именица од глаголских основа и базира се на томе што се глаголска парадигма мења са именичком парадигмом. У пронађеној српској грађи могуће је издвојити мушки тип са нултим суфиксом. Ова врста творбе скраћеница у српском фамилијарном језику је веома продуктивна, уп. нпр.: исфур т 1. 'избацивање'; 2. 'протеривање (из неке државе)' < исфурати vt 1. 'истерати, избацити'; 2. 'протерати (из неке државе)'; кец m 1. 'обмана'; 2. 'самообмана' < кецнутти (se) vt 'обманути (се), преварити (се)'; кок m 1. 'ударац'; 2. 'хитац' < кокати vi 1. 'тући'; 2. 'убијати'; 3. 'обављати сношај'; 4. 'ждерати'; 5. 'неумерено пити алкохолно пиће' [Рa, kok u glavu! 'Pa, udarac (ili hitac) u glavu (Имами 2007: 233)]; маз m 'крађа' < мазнути vt 1. 'украсти'; 2. 'отети'; 3. 'не питајући узети што'; 4. 'успети у удварању'; 5. 'преотети љубавног партнера' [maz! 'grabi!' (Имами 2007: 293)]; упиш т 'врло смешно' < упишати се (од смеха) vt 'смејати се јако много' [upišživi 'смешно да не може бити смешније'(Имами 2007: 514)] и сл.

И у пољском језику ћемо наћи доста примера сличних српским, нарочито оним насталим у најновијием времену. Занимљиво је, такође, што при оваквој творби могу да учествују и пропозиционе фразе у функцији прилога, сами прилози и, наравно, глаголи, уп. нпр.: naraska $\mathrm{f}<$ na razie!, do zobaczenia! 'ћао, довиђења, поздрав, збогом' или narka $\mathrm{f}<$ na razie!, do zobaczenia! 'ћao, довиђења, поздрав, збогом'; nawza f < nawzajem (прилог) 'такође'; brecht $\mathrm{m}<$ жарг. brechtać się vi 'смејати се' и сл.

\section{2. Синкопа}

Синкопа се етимолошки изводи из грч. sinkope 'ceћи, прекидати, сузети'. Ово је фонетска појава која се тиче губљења неакцентованог самогласника који стоји у средини речи (али може бити и губљење сугласника)

\footnotetext{
${ }^{12} \mathrm{http}: / /$ www.backatopola.in.rs/erotika/erotske_price_12.php.

${ }^{13} \mathrm{http}: / /$ www.mg-forum.net/index.php?showtopic $=2026 \&$ mode $=$ threaded $\&$ pid $=46730$.
} 
или губљење целог слога у вези с чим долази до скраћења речи (Полањски 2003: 580). Ова је појава типична за брзи, мање тачан, мање пажљив, или чак непрецизан, непажљив изговор. Она се може упоредити с пољским примерима (пољ. погрешно wogle - ispr. w ogóle 'уопште' ili trza - ispr. trzeba 'треба'). У српском и пољском фамилијарном језику/ жаргону синкопу можемо нађи много ређе него апокопу. У српској језичкој жаргонској грађи нашли смо само следеће именичке падежне и глаголске личне облике, уп.: б'ame! < brate! (Vok. 'iron. пријатељу!); изем < изједем 1. Sg j. [у смислу изјести 'уништити, убити'; izem Ti...! 'da ide do đavola...!' (Имами 2007: 189)]; мош < можеш 2. Sg j. (тоš misliti! 'можеш замислити'); мрш! (м'z!) < марш! 'губи се' [mrš odavde! 'губи се одавде!' (Имами 2007: 305)] и ша < шта [ša kaže? 'што говори?' (Имами 2007: 461)]. Овој групи такође припада скраћени облик броја јен $<$ један.

У пољском језику синкопе можемо наћи у примерима као што су: orginalny < oryginalny N. 'originalan' chrzesny < chrzestny N. 'kum', nastka $<$ nastolatka $\mathrm{N}$. 'tinejdžerka' или siora < siostra N. 'sestra'.

\section{3. Афереза}

Афереза се етимолошки изводи из грч. apheíresis 'одузимање, отимање, скидање'. Ова фонетска појава подразумева губљење гласа или гласова на почетку речи (Полањски 2003: 19). Афереза је у српском жаргону на другом месту што се тиче фреквентности творбе скраћеница, а само скраћивање се тиче губљења једног или два почетна слога. Због тога што се скраћивање врши на почетку речи, наравно, не долази до промене рода. Српски речници жаргона пружају различите скраћенице овог типа, као што су нпр.: бач < јебач m 1. 'мушкарац склон сексу'; 2. 'супериоран мушкарац'; бил < дебил m 1. 'глупан'; 2. 'ограничена особа'; блем < проблем m (пета blema 'нема проблема'; Kad budes menjao akumulator onda tad kupi sa tom amperazom $i$ njega i nета blema ${ }^{14}$ ); ияајаu < полицајаu m; изерт < кониерт m (mandarina $i$ ja ideто па сеrt ${ }^{15}$ ); ција < полиција f; деса < стјуардеса f; фон < телефон m; љубаи $\mathrm{m}<$ пољубаи $\mathrm{m} ;$ мић< грамић $\mathrm{m}$ 'грам дроге' и сл. У овом типу скраћивања можемо нађи такође два лична глаголска облика: бем ти <jebem ti 1 . Sg j. (Bem ti ove debile što sebe nazivaju ,,patriotama”'16) и шем < plešem 1. Sg j.

При аферези понекад такође може да дође до скраћивања самих жаргонизама и додавања суфикса женскога рода. У сакупљеној грађи два су таква примера, то јест: цана ф 1. 'млада проститутка'; 2. 'женски полни орган' $<$ исприана adj и сошка $\mathrm{f}<$ nacom $\mathrm{m}+-k a$ [Pretio je da će se dokopati soške... (Герзић Б./Герзић Н. 2002: 251)].

Што се пољског језика тиче, афереза, иако је позната у језику (уп. нпр. пољ. skra < iskra 'искра'), у фамилијарном језику је упадљиво одсутна. У

\footnotetext{
${ }^{14} \mathrm{http}: / /$ www.opelclub.rs/forum/viewtopic.php?t=49957.

${ }^{15} \mathrm{http}: / /$ twitter.com/\#!/billyjane/statuses/136138652161032192.

${ }^{16} \mathrm{http}: / /$ bemtisve.com/.
} 
сакупљеној пољској грађи пронађена су само три примера, то јест: bus < autobus 'најчешће у смислу комби', uj < chuj vulg. 'мушки полни орган' и bry $<$ dzień dobry' добар дан'.

\section{5. Закључак}

Поређење скраћивања речи у оба словенска језика доказује да наши језици имају велике сличности, а много мање разлика. Скраћени се облици јављају у сва три типа фонетских скраћеница. Највећи је број апокопа - како у српском, тако и у пољском језику. Што се тиче синкопе, она је такође присутна у српском и пољском фамилијарном језику, но ипак је то ређа појава. Занимљиво је да за аферезу, а у том случају се језици понешто међусобно разликују - у српском језику чешће долази до творбе аферезе него у пољском. У оба језика појава скраћења је обележје понајпре фамилијарног језика и жаргона, али један део скраћених облика прелази честом употребом у више жанрове, чак и у стандардни језик. Многе скраћене речи добијају наставке типичне за деминутив и премда немају изразито хипокористично значење, афективно су обојене и одражавају одређени ступањ присности с објектом који означавају (Мухвић Димановски 2001: 201). У српском, најчешћи је такав суфикс -uћ и по значењу се може упоредити с пољским суфиксом -ek (за женски род $-k a)$.

Природу фонетских скраћеница овог типа, наравно, правописи не узимају у обзир, све док такав облик не уђе у стандардни језик.

Сам проблем фонетских редукција везан је за сваки језик. Треба ипак нагласити да се српске жаргонске скраћенице, које су творене од вулгаризама, у многим случајевима могу рачунати као једна „врста еуфемизама”, зато што немају толико вулгарну нијансу као „вулгаризми у целости”, и често прелазе границу жаргона и општег језика. Такве скраћенице, на пример, могу се чути у српским позориштима, у којим глумци који учествују у некој позоришној представи замењују пуне вулгаризме њиховим скраћеним обликом.

\section{ИЗВОРИ}

Андрић 2005: Д. Андрић, Двосмерни речник српског жаргона и жаргону сродних речи, друго, знатно допуњено издање, Београд: Zepter Book World.

Правопис 2002: М. Пешикан, Ј. Јерковић, М. Пижурица, Правопис српскога језика. I. Правила и нњихови основи. II. Речник уз правопис, Нови Сад - Београд: Матица српска - Завод за уџбенике и наставна средства.

Хлебец 2006: Б. Хлебец, Енглеско-српски, српско-енглески речник сленга, друго, допуњено издање, Београд: Београдска књига. 


\section{ЛИТЕРАТУРА}

Акопџањан 2010: Ž. Akopdžanjan, Reči persijskog porekla u govoru naroda bivše Jugoslavije, Beograd: Društvo srpsko-iranskog prijateljstva.

Бугарски 2006: R. Bugarski, Žargon. Lingvistička studija, drugo prerađeno i prošireno izdanje, Beograd: Čigoja štampa.

Герзић Б./Герзић Н. 2002: B. Gerzić, N. Gerzić, Rečnik savremenog beogradskog žargona, Beograd: Istar.

Халиловић и др. 2010: S. Halilović, I. Palić, A. Šehović, Rječnik bosanskog jezika, Sarajevo: Filozofski fakultet u Sarajevu.

Имами 2007: P. Imami, Beogradski frajerski rečnik, III dopunjeno izdanje, Beograd: NNK International.

Кнежевић 2010: Z. Knežević, Čovek u žargonu (Semantičko-derivaciona analiza žargonizama sa arhisemom , čovek”), Beograd: Alma.

Кошћак 2018: N. Košćak, Šrajbenzi spiku? Stilovi hrvatske žargonske $i$ žargonizirane proze 1990-ih i 2000-ih, Stilistika.org; Filozofski fakultet Sveučilišta u Zagrebu - Odsjek za kroatistiku - Katedra za stilistiku, Zagreb 2018 <издање on-line: https://stilistika.org/zargon-i-kolokvijalni-jezik>31.10.2019.

Ласковски/Вробел 1964: Laskowski R., Wróbel H., Użycie paradygmatu w funkcji formantu słowotwórczego, Język Polski, Kraków, z. 4, 214-220.

Милојковић 2000: M. Milojković, Reči - rečnik đačkog žargona, Vršac: Viša škola za obrazovanje.

Мухвић Димановски 2001: V. Muhvić-Dimanovski V., Apokopa i afereza u funkciji jezične ekonomije, Suvremena lingvistika, Zagreb, Vol. 51-52 No. 1-2, 2001., 191-202.

Полањски 2003: K. Polański (red.), Encyklopedia językoznawstwa ogólnego, wydanie trzecie bez zmian, Wrocław-Warszawa-Kraków: Ossolineum.

Самарџија/Селак 2001: M. Samardžija, A. Selak, Leksikon hrvatskoga jezika i književnosti, Zagreb: Pergamena.

Скиба 2011: A. Skiba, Metateza w serbskim żargonie, Bałkański folklor jako kod interkulturowy, tom 1, red. J. Rękas, Poznań: Wydawnictwo Uniwersytetu Im. Adama Mickiewicza w Poznaniu, 405-412.

\section{Интернетски извори}

http://bemtisve.com/.

http://tweetmeme.com/story/5512429840/medija-centar-beograd.

http://witter.com/\#!/billyjane/statuses/136138652161032192.

http://vukajlija.com/zabava/posteri/245270.

http://www.backatopola.in.rs/erotika/erotske_price_12.php.

http://www.forum-srbija.com/viewtopic.php?f=1\& $\mathrm{t}=2 \&$ start=8980

http://www.ludomanija.net/vicevi/Chuck_Norris.htm.

http://www.mg-forum.net/lofiversion/index.php?t2026.html.

https://www.miejski.pl/. 
http://www.opelclub.rs/forum/viewtopic.php?t=49957.

http://www.putovanja.info/forum/topic/5362-jahorina/page_st_30.

http://www.vasisdas.pl/.

www.inkarp.com/Youtube/profile/TheGenocyd96/.

(приступ свим веб-страницама цитираним у раду од 10.09.2017. до 31.10.2019.)

Robert Bońkowski

\section{PHONETIC ABBREVIATIONS IN SERBIAN AND POLISH FAMILIAR LANGUAGES. SIMILARITIES AND DIFFERENCES}

\section{Summary}

The article addresses vocabulary in familiar language / conversational language / jargon in terms of the reduction of individual sounds and/or entire sound groups by Serbian and Polish people. Apocope, syncope and apheresis in one South Slavic and in one West Slavic language - that is, in Serbian and in Polish - were selected for analysis. A comparative method for the analysis of the elision in the two languages was employed in the paper. Analysis of the language material led to the conclusion that the Serbian and Polish familiar languages often use elision, all three types of phonetic abbreviations being present in both languages (with a slight deviation from the rule - only apheresis proved to be more common among Serbian than Polish people).

Keywords: Serbian language, Polish language, familiar language (speech), phonetics, elision. 